\title{
The Implementation of Penta Helix Counterinsurgency (COIN) Strategic Model in Reconstructing Special Autonomy for Papua
}

\author{
MHD Halkis \\ Department of Defense Diplomacy, Faculty of Defense Strategic, \\ Indonesian Defense University, 10430, Bogor Regency, West Java Province, Indonesia \\ Corresponding Author: halkis@idu.ac.id
}

\section{ARTICLE INFO}

Publication Info:

Literature Review

How to cite:

Halkis, M. (2020). The

Implementation of Penta Helix

Counterinsurgency (COIN)

Strategic Model in Reconstructing

Special Autonomy for Papua.

Society, 8(1), 234-248.

DOI : $10.33019 /$ society.v8i1.182

Copyright (C) 2020. Owned by Author(s), published by Society

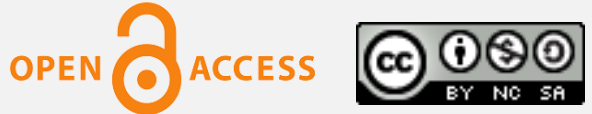

This is an open-access article.

\section{License: Attribution- \\ NonCommercial-ShareAlike (CC BY-NC-SA)}

Received: May 11, 2020;

Accepted: June 8, 2020;

Published: June 30, 2020;

\section{ABSTRACT}

The issues of Papua (Both Papua and West Papua Provinces) have been reached by international communities even though the government regulation; Law of the Republic of Indonesia Number 21, Year 2001, concerning Special Autonomy for Papua Province becoming a central issue as a problem solving to make a special treat for people in Papua internally. Whereas, the regulation is expected to make people in Papua develop political, economic, and cultural also resolving the insurgency problems among them. The arrangements of social and political, economy and budget are as a special treatment, only develop economy and infrastructure but it does not solve the conflicts until today. In this case, the Counterinsurgency (COIN) strategic model needs to be implemented following the appropriateness of national policy and the condition in Papua. This research used a content analysis method to reveal the causes of an un-optimal policy in solving the insurgency. Based on the four elements of COIN, only two elements exist; community and state elements. While the international community element and private sectors do not appear on the special autonomy legislation for Papua. As a reason, the COIN model appropriates with the condition of the people that include some elements; government, local community, the non-state, international community, and private sectors. Comparing to the United States of America (USA) model where the community is not included in the COIN element since the community as an object. On the other hand, it is different from China where military and political parties as important elements since the government decisions are supported by military force to solve the insurgency problem. This research found that civil and military cooperation in the model of COIN

Copyright $($ 2020. Owned by Author(s), published by Society. This is an open-access article under the CC-BY-NC-SA license.

https://doi.org/10.33019/society.v8i1.182 
Papua after special autonomy is reflected by the existence of Local Government Leaders Communication Forum of Papua to face all situations that happened in Papua, both in security and emergency. Active coordination among governors, local legislators, Adat communities (customary), police, and army for COIN strategy needs special coordination to global communities openly that affect opinions on the people and private sector interests in Papua.

Keywords: COIN; Conflict; Counterinsurgency; Papua; Penta Helix; Policy; Special Autonomy

\section{Introduction}

During the building integration process of a relatively young nation, the institutionalization of special organizations was identified as a critical point (Peretomode, 1985). Papua (Papua and West Papua Provinces, Indonesia) based on the Law of the Republic of Indonesia Number 21, Year 2001, concerning Special Autonomy for Papua Province has special organizations, both in accommodating the local community interests and in extending central government organizations in the regions. On the condition that the organization is formed and functioned wisely, the integration process of the development should proceed normally.

Ironically, in the last two decades, some events have indicated several group activities for those who conduct an insurgency to separate as part of The Unitary State of the Republic of Indonesia. A statement from the United Liberation Movement for West Papua (ULMWP) that three armed separatist groups in Papua claimed to have formed the West Papuan Army (Ramdhani, 2019). It is since the strategic considerations, the government claimed that as an insurgent, or commonly referred to as a term that was quite popular among the security forces, was the Armed Criminal Group, to hope the perpetrators would be placed as criminal acts so that they would be processed according to the law. However, academically, it is hard to place it as an insurgent and referred to as a criminal, then it results in a misguided concept and theory, as a result, the problems cannot be placed proportionally. Since 2018 this term has been added to "separatist" so that the law enforcement operation refers to the Armed Separatist Criminal Group. This term is also inadequate since the term "separatist" is not equal to the term insurgency. For this reason, many researchers call this effort to separate themselves from the Republic of Indonesia, called insurgents or insurgency.

Insurgency is a grassroots fight; the ability to identify, understands, and fights enemies where at this level, intelligence is needed among people. The efforts of government authorities in responding to their strengths both tactically and strategically in the best way according to existing capabilities are called Counterinsurgency (COIN) (Wayne, 2008). According to the United States Government Interagency Counterinsurgency Initiative (2009), COIN is a comprehensive blend of civilian and military, as an effort designed to simultaneously contain insurgency and address its root causes.

The conflict between insurgency vs. COIN is categorized as Asymmetric Warfare (AW). Galula (2006) stated that warfare as Irregular Warfare. According to Lele (2014), Asymmetric Warfare is a form of warfare in which a non-state actor uses unconventional tools and tactics 
against a state's vulnerabilities to achieve a disproportionate effect, undermining the state's will to achieve its strategic objectives.

The definitions above described that the actor of warfare is non-state or state subject as conventional warfare. Therefore, this research defines the warfare in Papua as an Actor of Asymmetric Warfare of Papua. This term can engage as the right understanding of conflict actors in Papua. In COIN strategy or strategy against the Asymmetric Warfare of Papua is difficult to point who will be responsible and take a long time, also it is difficult to blame over the responsibility of the warfare (Galula, 2006). Of the statement, the insurgents or the Asymmetric Warfare of Papua is suitable when criminal law as resolution. Insurgency is a political matter; therefore, the conflict must be resolved in a political framework. Furthermore, what and how the non-military incidents occur in a country both clear and unclear incidents are under national security. From a political perspective, Papua is part of The Unitary State of the Republic of Indonesia, so the Government of Indonesia must be responsible for the problems. Therefore, insurgency activities to separate from a country with an armed group are called insurgents.

According to Scott \& Tebay (2005), the insurgency in Indonesia is unable to resolve since the Government of Indonesia failed to implement the law of special autonomy. It is different from Myanmar where the country engages civilian involvement as an additional approach and slows, works in political structure but not to attack it (Pedersen, 2013).

However, the strategy undertaken in Myanmar is unlike the Asymmetric Warfare of Papua, in Myanmar, the problem of differences is not involved where it is different from the Papua culture. In this case, it needs a unique strategy against insurgency in the digital age. At present day, it is necessary to pay attention and opinions in the mass media, especially business and non-political media, since it is very dynamic and has very broad reach due to the technology and community involvement in using the media (Chen, 2012).

In Chinese military doctrine, against insurgency must meet three defined elements; society, party, and military (Singh, 2016). The three elements are synergized where it is different from the United State of America (USA) model. In the USA model, 4 elements become actors; international community, intergovernmental, non-governmental, and private sector (United States Government Interagency Counterinsurgency Initiative, 2009). Gordon McCormick as cited in Brizek \& Morris III (2007) also stated that four elements involved directly; state, society, non-state and international community. The difference between the USA Government and Gordon McCormick is in the community and private sector. For the USA, inter-governmental relations and the private sector are quite influential. This research chooses the model of McCormick, in which the fight between state and non-state, interactions with the parties that determine mutually limiting or disturbing. The McCormick Model COIN strategy can be described as follows: 


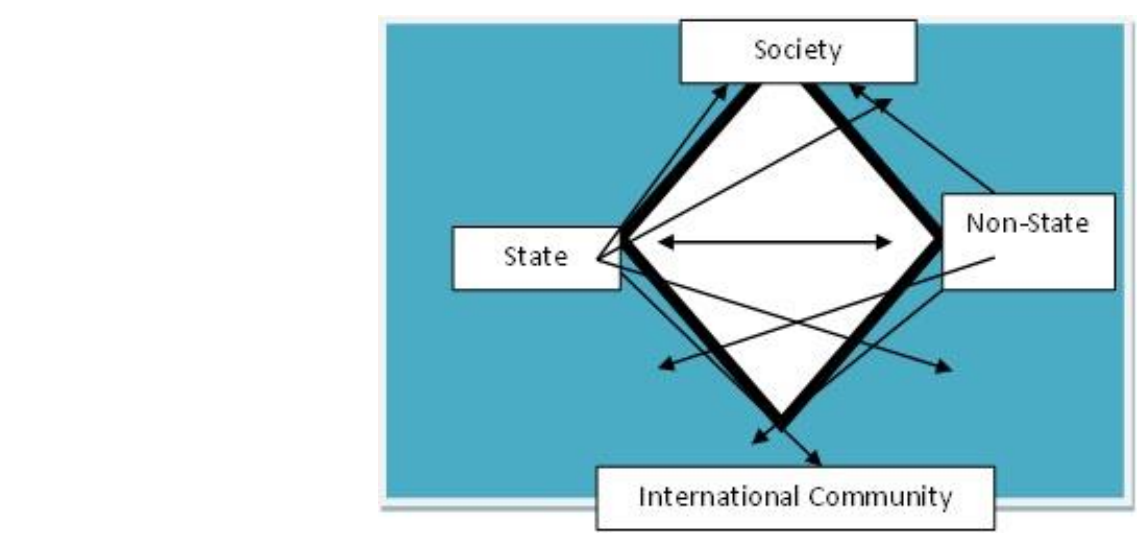

Figure 1. "The Mystic Diamond" model developed by Gordon McCormick as Counterinsurgency (COIN) Strategic Model

Source: Brizek \& Morris III (2007)

This model is suitable for the condition in Papua such as culture, history, and law. A postcolonial country like Indonesia faces many problems, ranging from the integrity of national identity to local and global politics included in the problem. Rehman (2018) stated that the political situation is a logical consequence in the colonialism context since ahead of the governments are formed and post-colonial can be institutionalized, the people must be convinced to provide support for nationalism and struggle for national goals.

\section{Literature Review}

The COIN strategy is based on an integrated central government decision along with the local government as an operational implementer to maintain political influence and legitimacy. It is to protect people from the violence of insurgents and to increase the legitimacy of the government by its people. As a consequence, the insurgent is isolated physically, psychologically, politically, socially, and economically (Joint Chief of Staff of the United States Air Force, 2018).

According to Galula (2006), COIN has four general actions of state; 1) direct actions against the insurgent leaders, 2) actions against conditions that triggered an insurgency, 3) infiltration of insurgent movements to make them ineffective, and 4) strengthening the political machine of a state. Whenever insurgency becomes up, the people will consist of favorable minorities, neutral majorities, and hostile minorities.

To overcome the insurgency problem with the COIN strategy, the most prominent is placing the minority in an advantageous position. For this reason, co-opting a neutral majority and in the process of neutralizing the threats posed by hostile minorities. COIN options are limited: the area must be chosen, freed from guerrillas. With minimal damage to the population, and remain peaceful by convincing residents that neutrality will result in the cessation of military activity.

The difference between COIN and conventional warfare is in community involvement. To against insurgency, it must involve all elements of the nation, not only the military, but political, economic, and cultural forces also determine (Galula, 2006). Conventional warfare separates combatants and noncombatants. The category of insurgency is orthodox and shortcuts. In the insurgency categorized as an orthodox pattern, the insurgents operate in a country of tolerable political action. They feel comfortable and feel unharmed, but in a strict country, they adhere more to the sporadic pattern so that the revolution becomes the choice for the country when they succeed. Generally, the problems are how to fight the insurgents, how to 
win the soul of the people by the government, and how the government protects the people from the effects of the movement.

Even though the COIN strategy emphasizes civilian capacity in dealing with insurgents, general construction remains within the framework of national defense preparedness. It means that if the escalation increases unexpectedly at a certain point the military must always be awakened. Civilian and military emergencies remain in the worst-case scenario (Joint Chief of Staff of the United States Air Force, 2018).

Before a COIN strategy is undertaken, the strategies of the Asymmetric Warfare of Papua must be understood; such as 1) to understand the opportunities that allowed the movement formed, grew, and developed; 2) to understand the real motivation of the insurgency. Did it mean to establish a country, or other motives such the dissatisfaction? 3) to separate the militant groups and the society at large; 4 ) to understand the efforts of supported groups domestically and internationally, both donations and diplomacy. At this point is to understand the object, such as the organizational structure of the insurgent.

The state must have power, adaptation, and coherent political institutions: effective bureaucracy, organized with good political parties, high level of community participation, working systems of civilian control over the military, extensive activity by the government in the economy, and reasonably effective procedures for regulating succession and controlling political conflict for that every country is a political community (Huntington, 2006). The process of uniting sub-communities to build political communities through a long process and tends to never be satisfied.

According to Parekh (2000), the process of integration is also motivated by history, cultural structure, and diversity, so that the solution to the problem is through multicultural paths. In a multicultural issue, the national identity is not single, but it is developing and flexible. This multiculturalism theory makes it possible to understand the development of Papua's Special Autonomy; to this day the turmoil and activities of the Asymmetric Warfare of Papua still exist even though it is latent.

The strategic model to deal with insurgents is related to coordination and escalation. In a certain escalation, it requires certain coordination patterns. The escalation is both a normal state of civil order and an emergency. In an emergency based on Government Regulation in Lieu of Law of the Republic of Indonesia Number 23, Year 1959 concerning Emergency Conditions, there are three conditions; civil emergency, military emergency, or martial law. The determination of these conditions based on this Law depends on the President as the Supreme Commander.

The multilevel coordination pattern is governed by how coordinated when the government acts, and how to coordinate horizontally between local governments. The strategy is not synonymous with policy. Professor Alan Stolberg explained that "policy is what must be done; a strategy is how to do it". Professor Richard Yarger resumed as "strategy is about how (ways or concepts) leaders will use the strengths (means or resources) available for control over the state's set of circumstances and geographical locations to achieve goals (ends) that support the interests of the country", (Borer et al., 2011).

\section{Research Methodology}

This study used a content analysis method. Leedy \& Ormrod (2001) define content analysis as a detailed and systematic examination of the contents of a particular body of material to identify patterns, themes, or biases. It is usually to identify patterns of human communication

Copyright $($ 2020. Owned by Author(s), published by Society. This is an open-access article under the CC-BY-NC-SA license. https://doi.org/10.33019/society.v8i1.182 


\section{The Implementation of Penta Helix Counterinsurgency (COIN) Strategic Model in Reconstructing}

Special Autonomy for Papua

included books, newspapers, private journals, movies, televisions, arts, music, recorded audios, legal documents, transcripts of conversation, blog entries, and bulletin systems.

This study was to identify COIN patterns, themes, strategies, or models in Papua. The steps were undertaken as formulated by Leedy \& Ormrod (2001) described as follows: Firstly, identifying the institutions established under the Law of the Republic of Indonesia Number 21, Year 2001 concerning Special Autonomy for Papua Province and central government institutions in the regions to support the integration of the nation in Papua in general, these institutions; The Papua Regional Government, the People's Representative Council of Papua (DPRP), the People's Assembly of Papua (MRP), the Papua Provincial Police, the Indonesian National Army (The XVII/Cenderawasih Regional Military Command), and the Papua Regional State Intelligence Agency. These institutions are the subject of research.

Secondly, precisely defining the problem discussed, that this study addresses the problem of overcoming insurgency or counterinsurgency (COIN), not criminal acts, even though there are still operations being held that are still called law enforcement. Strategies undertook by the subject in the context of overcoming or resisting the insurgency. COIN was the object of this research.

Thirdly, describing the elements associated with the COIN model. To understand the existing models, researchers first understand the existing COIN models, both Chinese, USA, or experts. Fourth, assessing the elements under the functions and roles that they do. Thus the researcher can model the current operating model in conducting COIN in Papua. Fifth, revising the model by criticizing the existing model, and then offer improvements to the new model as a solution going forward. Thus, the suggested model is a combination process of various models that are considered relevant to the current problems.

\section{Results}

The Law of the Republic of Indonesia Number 21, Year 2001 concerning Special Autonomy for Papua Province is not prepared directly to overcome the Asymmetric Warfare of Papua, but it is possible to be potentially developed in the reconstruction of COIN strategy of Papua. The combination of elements such as indigenous peoples, local government, and the central government (police and military) in COIN has worked well, but it needs to be complemented with inherent elements to deal with the international community and the private sector. Until today, by this approach to the Papua Special Autonomy Law, public awareness has increased to remain faithful to the results of the referendum that has been inherited since 1969.

The approach is responsive since it is explained in the contents that to regulate and manage the interests of local communities according to their initiatives based on the aspirations and basic rights of the people of Papua, even police duties in the field of public order and peace that should be pure from the central government but in Papua special autonomy law a Provincial Regulation has been regulated.

Following the constitution of the 1945 Constitution of the Republic of Indonesia that the defense and security system of the Republic of Indonesia adheres to the defense system of all people, the interpretation of this article places all resources in society used to support defense and security issues. If some community members attempt to out of the Republic of Indonesia by this understanding, then the community itself will overcome it. For this reason, the empowerment of indigenous peoples is involved in the governance structure, including in the context of implementing the universal defense system. For this reason, the current coordination pattern is part of the implementation of the universal defense system so that it can be called the COIN-Papua strategy.

Copyright ( ) 2020. Owned by Author(s), published by Society. This is an open-access article under the CC-BY-NC-SA license. https://doi.org/10.33019/society.v8i1.182 
The current coordinated pattern is a pattern of interaction and coordination between the community, regional government, central government (especially the police, military, and the Regional National Intelligence Agency). This coordinated system illustrates the flexible system to deal with different situations and conditions, such as safety and emergency conditions which can be described as follows;

\subsection{Security Situation}

Insecurity situation or community in order, the policy, and strategy to deal with the insurgency are regulated by the Papua Regional Government consisting of the executive governor and the legislative assembly. Then the representation of the community component is gathered in the Papua People's Assembly which considers the regional government. The MPR along with other components of civil society, especially indigenous people who in touch with the public and academics who work for community development and regional progress.

According to Musa Isir (2018), the Head of the National Unity and Politics Agency of Papua Province, in a security situation, the Government of Papua performs its functions as same as other regions in Indonesia. In facing the Civil Emergency, the Governor of Papua can use the Regional Leadership Communication Forum to overcome the situation until it returns to normal. According to the Chief of the Provincial Police to maintain national security can be in three phases:

1) Prevention, although police officers are lacking in number, it can empower the community.

2) Countermeasures, the legal awareness of the community is still low so that it is necessary to socialize positive law.

3) Law Enforcement, the geographical landscape of Papua is very broad and many communities still use customary law in resolving conflicts, including tribal warfare. The solution is done by supporting the mobility of the authorities to the regions and crosssectoral coordination.

\subsection{Emergency Situation}

According to the Chief of Staff of the XVII/Cenderawasih Regional Military Command, Brigadier General Herman Asaribab, it is important to define what the insurgency is and the rules for its implementation and how to handle a state of emergencies such as civil emergency, military emergency or martial law. Armed Criminal Group that means handled criminality, evidence of arresting, and legal proceedings. At present, Papua is not martial law, not even a civil emergency, similar to other regions in Indonesia. The function of the Regional Military Command as the Operation Implementation Command of the Indonesian National Army (KOLAKOPS TNI) is based on Commander of the Indonesian National Army Regulation Number 6/II/2010 concerning the Indonesian National Army Assistance and the Indonesian National Army Commander's Decree Number SPRIN/71/VIII/2011 concerning Implementation Manual regarding the Indonesian National Army assistance to the National Police in the framework of Security and Public Order. However, the Indonesian National Army's readiness is maintained even in the worst conditions.

The XVII/Cenderawasih Regional Military Command in dealing with the Asymmetric Warfare of Papua is not regulated in the Special Autonomy Law for Papua Province, but in Law of the Republic of Indonesia Number 7, Year 2012 concerning Social Conflict Management can be used as a basis for the Indonesian National Army. This law mandates that Article 33 regulates the status of conflict conditions in the region, regional officials following their level, may request assistance using the Indonesian National Armed forces, and in article 34 paragraph

Copyright ( $(2020$. Owned by Author(s), published by Society. This is an open-access article under the CC-BY-NC-SA license. https://doi.org/10.33019/society.v8i1.182 
(1) mandates that the implementation of assistance using the Indonesian National Armed force is coordinated by the Police. On this basis, the Indonesian National Army regulates the COIN strategy: Firstly, the goal of the operation is to uphold the law. Law enforcement is the domain of the National Police; these activities are mentioned as assisting the National Police. Law enforcement support from the Indonesian National Army is currently providing personnel assistance in law enforcement operations to deal with the Armed Separatist Criminal Group under police control.

Secondly, three main activities to help these activities carried out by the XVII/Cenderawasih Regional Military Command, namely in the field of intelligence, territoriality, and combat. Each section has its operational structure and activity but in an integrated whole.

Thirdly, the approach used is religion, culture, and welfare. This approach was taken since the Chairperson of the Papua Customary Council (Forkorus Yaboisembut, S.Pd) and the Regional Customary Council, General Chairperson of the Papua Task Force (Boy Eluay), and General Chairman of the Papua Land Guard (Philipus Elias Ayakeding) had sought to fight for Free Papua through Customary Pathways (according to interview result with the Papua People's Assembly Secretary-General and the XVII/Cenderawasih Regional Military Command documents, 2018).

According to Musa Isir, the Head of the National Unity and Politics Agency of Papua Province, the most popular problems faced by the Papua Regional Government are three issues; historical rectification of determination of the Act of Free Choice, alleged human rights violations, and recognition of basic rights of Papua. In addition to the three main issues raised by the Asymmetric Warfare of Papua, according to Inspector General Boy Rafli Amar, the Chief of Regional Police of Papua Province, explained that the motivation of the people to join the separatist movement was due to economic motives and work. It is important to see motivation associated with efforts to win people's hearts (Movanita, 2018).

The Focus Group Discussion (FGD) at the XVII/Cenderawasih Regional Military Command in 2017 revealed that the results of the 2016 Operations recorded 93 firearms, 5 grenades, and 287 munitions. The Asymmetric Warfare of Papua leaders from the Tingginambut area who surrendered was Teranus Enumbi along with 196 sympathizers and 9 others who were captured. The Paskhasau Task Force also found 2,999 bottles of liquor and 500 grams of dried marijuana. These results are expected to support the creation of security stability in the Operation Command of the Indonesian National Army (KOOPS TNI) region in Papua. Roughly speaking, the Armed Movement Group of the Free Papua Movement is divided into three; they are a) Hans Uri Yuweni Group (Commander of the National Liberation Army/Free Papua Movement, Markas Victoria). This group is actively carrying out activities of armed security disturbances in the North Coast region of Papua (Memberamo, Yapen, and around Wembi); b) Mathias Wenda Group (Commander of the National Liberation Army/Free Papua Movement, Pemulih Keadilan). This group is actively conducting security disturbance activities in the Republic of Indonesia-Papua New Guinea border region and Jayawijaya regency; and c) Tabuni Goliath Group (Supreme Commander of the National Liberation Army/Free Papua Movement, mountainous region). This group is actively carrying out security disturbance activities in the Puncak Jaya, Puncak, Timika, and Paniai regions (FGD at the XVII/Cenderawasih Regional Military Command, 2018). Then the Supreme Commander of the West Papua Revolutionary Army, Mathias Wenda, has signed the West Revolutionary Law, which took effect on September 13, 2016, which is precisely on the day the United Nations Declaration on the Rights of Indigenous Peoples was issued at the United Nations General Assembly in New York, 2007.

Copyright (C) 2020. Owned by Author(s), published by Society. This is an open-access article under the CC-BY-NC-SA license. https://doi.org/10.33019/society.v8i1.182 
The movement and strength of the Asymmetric Warfare of Papua have been anticipated by the government from various dimensions. The Asymmetric Warfare of Papua has militant movements both foreign and domestic combatants. On the other hand, the foreign interests of the PT Freeport Indonesia gold mine are also one of the problems. President Joko Widodo explained that the development of Papua is more important. Freeport multinational companies face legal problems with Indonesia. Papua seems to be a struggle since it has the biggest gold mine in the world (around \$ 100 billion). However now the area is the territory of the Republic of Indonesia, but the area is inseparable from the problem of insurgency.

From the description above, it can be seen the dynamics in the field in implementing Papua's special autonomy. Government is more faced with internal problems, which can be described in the following model:

\section{MODEL (GOVERNMENT POWER STRUCTURE) PAPUA COUNTER-INSURGENCY}



Figure 2. Policy model of Counterinsurgency (COIN) Papua to support the welfare of people in Papua after Special Autonomy

In the Asymmetrical Warfare perspective, a typical regional autonomy policy for Papua can support Papua's current COIN strategy model using elements of society and government. If it is compared to the "Mystical Diamond" model developed by Gordon McCormick which not an element of the international community is yet. It happens since Indonesia in foreign affairs is the central government, the representatives of the central government in the regions are aware of such problems, but the limitations of authority and responsibility are unitary state issues in nature. 


\section{The Implementation of Penta Helix Counterinsurgency (COIN) Strategic Model in Reconstructing Special Autonomy for Papua}

If COIN-Papua is compared with the Chinese model, it seems that the use of the TNI in Papua is passive. This is understandable in the condition of Papua in the security situation; it will be different if in an emergency. When compared with the USA it seems that the COINPapua strategy does not have a network of international communities and the private sector. Then the COIN USA strategy places the community as an object, but the direction and movement of the community are not influenced by internal government, but between the state, the international community, and the private sector. For this reason, the USA strategy needs to be considered, since besides having an interest in the USA strategy in the Pacific region, PT. Freeport Indonesia is part of a multinational company from the USA. Of course, this view is considered incompatible with the original view of Indonesia, but looking at the PPA-Papua movement in the perspective of Indonesian defense diplomacy, when rethinking the COINPapua strategy model.

The government is trying to eliminate separatist problems in Papua, both through lobbying abroad and approaching all stakeholders in Papua. The referendum movement of the people of Papua who demanded the release of the Unitary State of the Republic of Indonesia by Benny Wenda and his friends not only used local community networks but had entered the international community. Demmak Organization (Koteka Community Consultative Council) demands recognition and protection of the customs, as well as beliefs, of the ethnic Papuan people. They reject anything offered by the Indonesian government including special autonomy.

Efforts to explain that the Special Autonomy of Papua within the framework of the Unitary state of the Republic of Indonesia is the best solution to the problem of Papua is also carried out to correct and position the Papua problem clearly and objectively. Another step taken by the government is to continue to encourage regional governments to carry out Special Autonomy that can utilize the special autonomy funds appropriately for improving the welfare of the community, especially in the fields of education, health, and other social problems.

At the international level, the steps taken by the government are to present positive developments in Papua, for example concerning the success of Papua's Special Autonomy, Education, Health, Elections, and Presidential Instruction for accelerating development, community development, and security approaches through welfare. The emergence and development of separatism at the embryonic stage are inseparable from the problem of injustice and welfare disparities so that to overcome this, the government will continue and develop the policies that have been taken so far. The approach to the problem of separatism is no longer merely using military force but is using top priority to make persuasive steps with the approach of peace and dialogue and improving welfare through equitable development.

The concept of a "dignified" peace resolution will continue to be applied in the prevention and overcoming of separatism in other regions. The "dignified" resolution aims to ensure that separatists will not lose to give up their aspirations. Strengthening the community support base through political and customary institutions, such as the Papua People's Assembly (MRP) and the Papuan Customary Council (DAP) is a major milestone to reduce dissatisfaction and dissent between local communities and the Central Government.

To ensure the success of this approach, a comprehensive evaluation of government policies and strategies is regularly conducted. Improvement of public services, especially to obtain correct information, is carried out so that the socialization of the importance of maintaining the integrity of the Unitary State of the Republic of Indonesia can be conducted properly. Military policy is the final step and will only be taken if the problem cannot be resolved through dialogue.

Copyright (C) 2020. Owned by Author(s), published by Society. This is an open-access article under the CC-BY-NC-SA license.

https://doi.org/10.33019/society.v8i1.182

243 
If the elements of the USA and China strategies blended in Papua COIN, Indonesia can provide space in the structure of COIN Papua to build Confidence Building Measures (CBMs) to the people and the international community. In CBMs three issues need attention; negotiations, decision-makers, and broader constituents (Mason \& Siegfried, 2013). These three issues become part of the task of defense diplomacy, especially negotiations in the defense field. For this reason, practically Representatives of the Indonesian Ambassador in relevant countries such as the Republic of Vanuatu and the Solomon Islands can be represented by the Indonesian Defense Attaché from the Australian Embassy.

From an international political perspective, among others, it is possible to deal with Indonesian defense diplomacy, as stated by United Liberation Movement for West Papua (ULMWP) Spokesman Benny Wenda, that Indonesia has no seriousness in dialogue with the people of Papua. Therefore, he said he would focus the struggle to bring the problem of Papua to the United Nations (UN). The ultimate goal is the holding of a referendum on selfdetermination under the supervision of the United Nations (Doherty, 2019). Benny Wenda's efforts were also included in the Melanesian Spearhead Group (MSG) meeting agenda, but in 2016 discussing the existence of UMLWP did not bring a meeting point since criteria had not yet been agreed upon to become full members of MSG (Fadhilah, 2019).

This illustration shows that the phenomenon of the Papua problem is not enough to develop strategies in fostering Papuan society itself, but Indonesia used the potential of defense diplomacy in dealing with the international community and the private sector so that a possible model can be described in the Penta Helix model as follows:

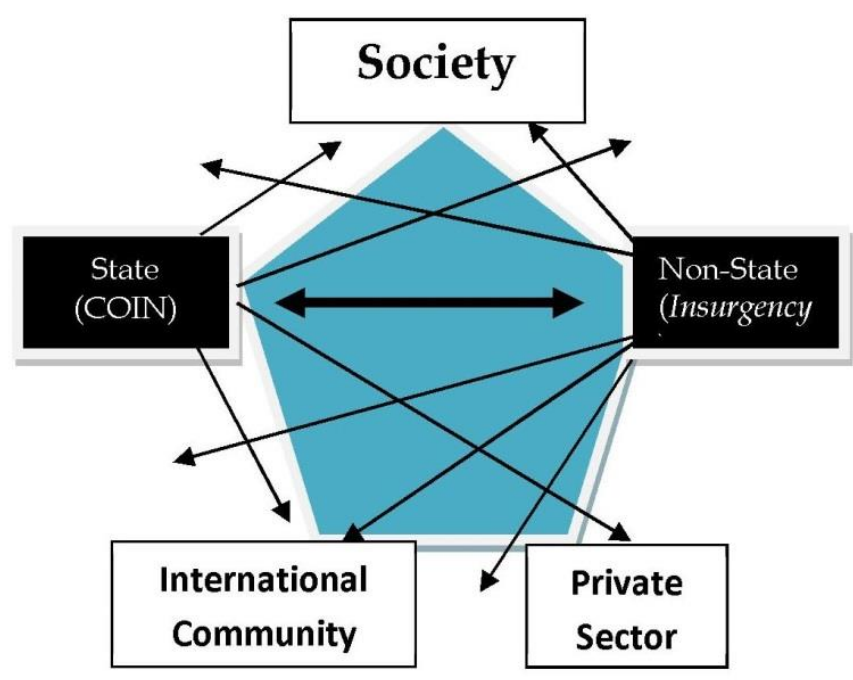

Figure 3. Penta Helix Strategic Model of COIN-Papua

In the strategy, COIN fighting is between non-states as insurgents and state that conduct COIN (pictured in the black box). Other elements, free in nature, can support non-state or state, or both ambiguously. Each party attempts to get support from both, the community and the international community, and the private sector (arrows pointing towards the target). Each party also tries to prevent the opposing party from getting the support of the parties (one party's arrow restricts the other party's arrow).

The difference between the Penta Helix and the Mystical Diamond Models lies in the addition of elements of the private sector. Even though the majority share is now controlled by 
the government, operational management remains under the control of multinational companies.

\section{Discussion}

Public policy through the Papua Special Autonomy Law has succeeded in supporting the welfare of the people of Papua. But the strategy in dealing with the Asymmetric Warfare of Papua needs to be improved. When compared to the elements involved in COIN, the Chinese strategy model with Papua's COIN policy has been almost fulfilled, namely there are elements of society, government (party), and the military. The difference is that the Chinese military is operational, not supporting the police for law enforcement as it is now in Indonesia. However, compared to the USA strategy, there is no visible involvement between the government, the international community, and the private sector. This means that the approach taken is more similar to Chinese strategy, but softer since it does not prioritize the military. When compared with the Diamond Mystical model, look at the elements of the international community. However, looking at the comparison of this model and the events that colored the Asymmetric Warfare of Papua movement, it seems that the existence of the international community and the private sector must be taken into account. The next question is of course how to respond to these needs in an existing system or formulate a new system.

The typical COIN-Papua policy now looks stronger to support the welfare of the community than facing the Asymmetric Warfare of Papua; in the ranks of the government, it does not consider the Asymmetric Warfare of Papua as a threat, merely a "naughty" of children of the nation. Besides, there is no courage in establishing Papua in the emergency zone but is used by certain individuals with these conditions. As a result, 4 state actions as Galula (2016) suggested in the COIN strategy were ineffective, especially against the Asymmetric Warfare of Papua infiltration so that government policies are ineffective and strengthen the government's machine of politics.

For this reason, David Galula attempts to enforce the law is not effective in the COIN strategy, since an insurgent is irrelevant and it is only accounted as criminal acts, but the government must demand what their promises and commitments are and in supporting national unity. The Papua conflict in the framework of the Asymmetric Warfare places the insurgency as the subject. Since it is not classified as conventional warfare, the command structure and combat team are not clear, so the solution is COIN. However, it cannot solve the problem but only by criminal acts through the legal or customary network.

If Huntington said that the state is a political community, then Papua is an incomplete political community in Indonesia. Since the Act of Free Choice 1969 that Indonesian sovereignty has been recognized internationally, the existence of Papua still has a special record in Indonesian history. The treatment of the central government towards Papua remains different compared to other regions. Even though it looks spoiled, but still like the youngest child who always asks for priority. For example, there is no community to become a governor through the ratification of indigenous peoples, but in Papua the validation of prospective governors by indigenous peoples. It means that only descendants of Papua can be the governors of the region.

According to Parekh (2000), the integrity of a nation is influenced by history and diversity of identities. The exploration of the history of the Act of Free Choice became an issue considered important in the Papua movement that was understandable since there was a political sovereignty present. Dualism between the central government and regional 
governments seems contradictory. In this way, the strength and culture of indigenous peoples are questioned in the formation of living law.

On the other hand, according to Söderbaum (2011), regionalism can also be part of the postWestphalia governance model (that is, beyond the nation-state system) of regional communities that live side by side. By comparison with globalization led by economics and markets, regionalism is more bound to the territorial domain. If the Papuan issue is seated in the Melanesian Regional section, then the Papuan entity is not intact, it cannot be a subject of law in international treaties, but it will still be a potential for discussion in the international community both regionally and UN level.

\section{Conclusion}

The Government of Indonesia in the resolution of Papua has used special policies under the defense and security system adopted, namely by prioritizing approaches to community politics, people's economy, and social welfare. The Province of Papua is special with the involvement of indigenous peoples and the placement of community power in a security situation supported by sufficient budget and broad authority to improve the economic welfare of the community.

However, from the opportunity, motivation, and parties who strive to separate Papua from the Republic of Indonesia within the framework of national defense, it is necessary to develop a special strategy. A coordinating framework for communication in emergencies between local government, police, military, and defense diplomacy to deal with the international community and the private sector. The implementation of the Special Autonomy Law and the efforts of the Central Government during President Joko Widodo's reign are quite impressive and have had a positive impact on society. These efforts in David Galula's perspective include efforts to overcome the insurgency triggers. It is hoped that the Asymmetric Warfare of Papua can confine its intentions and actions. Furthermore, it needs support for defense diplomacy and general diplomacy by the Papuan diaspora abroad. Then the effort to fight against the Asymmetric Warfare of Papua leaders needs to be consistent in supporting the command of the Indonesian National Army operations.

Community service to control; security, politics, and economics within the framework of Special Autonomy have been conducted. The division of tasks of the Indonesian National Army and Indonesian Republic Police goes on to deal with the issue of security and synergy, the Governor and Deputy Governor, even the Regent and Mayor are sons of the soil as political control, and the distribution of natural resources is greater through the distribution of Freeport shares to the Papua Regional Government. Cultural efforts in special autonomy by bringing up the Papuan People's Assembly and the Papuan People's Representative Council (DPRP) are an appropriate strategy model to support COIN-Papua. The Papuan People's Assembly (MRP) is a body whose duty is to protect and maintain the identity of the Papuan people and is appropriate for approaching separatist activists since it can establish lines of communication with the grassroots. Then the Papua People's Representative Council (DPRP) functions as a regional legislative body. Formally, power in the regions is in the hands of the governor, but in carrying out its tasks in an integrated way with the MRP and the DPRP. The Governor as the representative of the government is backed up directly by elements of the central government.

\section{Acknowledgment}

The author is grateful to express gratitude to all of those who have had the pleasure to work during this research conducted. 


\section{Declaration of Conflicting Interests}

The author declared no potential conflicts of interest concerning the research, authorship, and/or publication of this article.

\section{References}

Borer, D., Freeman, M., \& Twing, S. (2011). Strategy. In M. Freeman \& H. Rothstein (Eds.), Gangs and Guerrillas: Ideas from Counterinsurgency and Counterterrorism (pp. 13-14). Retrieved from https:/ / www.hsdl.org/?view\&did=6229

Brizek, J., \& Morris III, E. C. (2007, June). A non-conventional interdiction strategy for the global war on terror (Thesis). Monterey, California: Naval Postgraduate School. Retrieved from https:/ / calhoun.nps.edu/handle/10945/3485

Chen, P. J. (2012). Australian Politics in a Digital Age. Canberra: ANU Press. https://doi.org/10.22459/APDA.02.2013

Doherty, B. (2019, August 12). Indonesia anger as West Papua independence raised at Pacific forum. Retrieved from https://www.theguardian.com/world/2019/aug/12/indonesiaangered-as-west-papua-independence-raises-its-head-at-pacific-forum

Fadhilah, M. (2019). Inkonsistensi Kebijakan Luar Negeri Melanesia Spearhead Group (MSG) dalam Isu Papua Barat: Studi Kasus Fiji dan Papua Nugini. Indonesian Perspective, 4(1), 5981. https:/ / ejournal.undip.ac.id/index.php/ip/article/view/24480

Söderbaum, F. (2011). Formal and Informal Regionalism. In T. M. Shaw, J. A. Grant, \& S. Cornelissen (Eds.), The Ashgate Research Companion to Regionalisms (International Political Economy of New Regionalisms Series ed., pp. 51-67). Burlington, Vermont: Ashgate.

Galula, D. (2006). Counterinsurgency Warfare: Theory and practice. Westport, Connecticut: Praeger Security International.

Huntington, S. P. (2006). Political order in changing societies. New Haven, Connecticut: Yale University Press.

Joint Chief of Staff of the United States Air Force. (2018, April 25). Counterinsurgency. Retrieved from https://fas.org/irp/doddir/dod/jp3_24.pdf

Leedy, P. D., \& Ormrod, J. E. (2001). Practical Research: Planning and Design. Upper Saddle River, New Jersey: Merrill Prentice Hall.

Lele, A. (2014). Asymmetric Warfare: A State vs Non-State Conflict. OASIS, (20), 97-111. https://revistas.uexternado.edu.co/index.php/oasis/article/view/4011

Mason, S. J. A., \& Siegfried, M. (2013). Confidence Building Measures (CBMs) in Peace Processes. In Managing Peace Processes. A handbook for AU practitioners (Vol. 1, pp. 57-77). Addis Ababa, Ethiopia: African Union (AU) \& Centre for Humanitarian Dialogue (HD Centre). $\quad$ https://www.hdcentre.org/wp-content/uploads/2016/07/AU-HandbookVolume-I-Process-related-questions-July-2013.pdf

Movanita, A. N. K. (2018, January 4). Kelompok Kriminal Bersenjata di Papua Berpotensi Ganggu Proses Pilkada. (D. Meiliiana, Ed.), Kompas.Com. Retrieved from https:/ / nasional.kompas.com/read/2018/01/04/19190651/kelompok-kriminal-

bersenjata-di-papua-berpotensi-ganggu-proses-pilkada

Parekh, B. (2000). Rethinking Multiculturalism: Cultural Diversity and Political Theory (1st ed.). London, United Kingdom: Macmillan Pub https://doi.org/10.1177/146879680100100112 
Pedersen, M. B. (2013). How to promote human rights in the world's most repressive states: lessons from Myanmar. Australian Journal of International Affairs, 67(2), 190-202. https://doi.org/10.1080/10357718.2013.764581

Peretomode, V. P. (1985). Political Parties and Problems of National Integration: a Case Study of the Federal Republic of Nigeria (Master's dissertation). Oklahoma, United States of America: Faculty of the Graduate College of the Oklahoma State University. Retrieved from https:// shareok.org/bitstream/handle/11244/17408/Thesis-1985-P437p.pdf?sequence=1

Ramdhani, J. (2019, July 4). TNI Respons Separatis Bersenjata: Papua Diakui Dunia Bagian NKRI. Retrieved from https://news.detik.com/berita/d-4610617/tni-respons-separatisbersenjata-papua-diakui-dunia-bagian-nkri

Rehman, M. A. (2018). Nation as a Neo-Idol: Muslim Political Theology and the Critique of Secular Nationalism in Modern South Asia. Religions, 9(11), 355. https:// doi.org/10.3390/rel9110355

Scott, C., \& Tebay, N. (2005). The West Papua conflict and its consequences for the Island of New Guinea: Root causes and the campaign for Papua, land of peace. The Round Table, 94(382), 599-612. https:// doi.org/10.1080/00358530500331826

Singh, P. K. (2016). Changing Contexts of Chinese Military Strategy and Doctrine. New Delhi, India: Institute for Defence Studies and Analyses.

United States Government Interagency Counterinsurgency Initiative. (2009, January). U.S. Government Counterinsurgency Guide. Retrieved from https:/ / www.hsdl.org/?view\&did=38828

Wayne, M. I. (2008). China's War on Terrorism. London: Routledge. https://doi.org/10.4324/9780203936139

\section{About the Author}

MHD Halkis, obtained his Doctoral degree in Philosophy from University of Indonesia, in 2014. The author is an Assistant Professor at the Department of Defense Diplomacy, Faculty of Defense Strategic, Indonesian Defense University, Indonesia. Also, the author of a book entitled "Konstelasi Politik Indonesia: Pancasila dalam Analisis Fenomenologi Hermeneutika", published by Yayasan Pustaka Obor Indonesia, Jakarta, 2017.

E-Mail: halkis@idu.ac.id 